\title{
A forgotten Jewish-Portuguese historian of medicine: Dr. Augusto Isaac d'Esaguy, OSE, | 899-| 96 |
}

Journal of Medical Biography 0 (0) $1-4$

(C) The Author(s) 2018 Article reuse guidelines: sagepub.com/journals-permissions DOI: $10.1177 / 0967772018800805$ journals.sagepub.com/home/jmb

(S)SAGE

\author{
Avi Ohry' and Maria de Fátima Nunes ${ }^{2}$
}

\begin{abstract}
Augusto Isaac d'Esaguy was a 20th century Portuguese medical historian who made contributions to the history of Portuguese-Jewish physicians and was also involved with the Jewish-Portuguese Refugee Committee which assisted with the relocation of Jews from Nazi-controlled France during the Second World War.
\end{abstract}

\section{Keywords}

Augusto Isaac d'Esaguy, history of medicine, Jewish-Portuguese medicine, Portugal

Cease all that antique Muse hath sung, , for now a better Brav'ry rears its bolder brow. (The Luiciades, by Luiz Vaz de Camoens, 1572, translated by R F Burton, 1880, London)

The poet is a man who feigns

And feigns so thoroughly, at last

He manages to feign as pain

The pain he really feels,.... (Fernando Pessoa (1888-1935), Autopsychography, Translated by Edouard Roditi)

\section{Biography}

Augusto Isaac d'Esaguy was born in Faro, Portugal, in 1899. His father, Isaac Augusto d'Esaguy, was born in 1869 in Capo Verde, and his mother, Raquel ToledanoBensimon, was born in E'vora. Augusto had three brothers and sisters. ${ }^{1}$ Later Augusto moved to Lisbon. In 1923, whilst still a medical student, he married Sylvia Cohen Israel whom he later divorced.

He became a journalist before graduating in Medicine. In 1918, he served as a Secretary to the Minister of Foreign Affairs, Prof. Egas Moniz. At this time, he was described as tall, thin, affable, and friendly. He could be found in places like the Cafes do Chiado, Lisbon's cultural centre, or at work in the hospital. $^{2}$
According to the information given in 1932 by the Gazeta dos Caminhosde Ferro (the Railway Revue), ${ }^{3-5}$ and the Jewish Physicians' biographical Index, ${ }^{6}$ d'Esaguy graduated in Lisbon 1926 and became a lecturer in history of medicine at his alma mater. Later he specialized in dermatology in Paris, and became a practicing dermatologist in Lisbon. From 1932, he published articles on dermatology and specifically on syphilis.

His cultural and literary contributions, mainly on the history of Portuguese-Jewish physicians, gained him the title "OSE," The Military Order of Saint James of the Sword (Portuguese: Ordem Militar de Sant'Iago da Espada) which is a Portuguese order of chivalry. It was a distinction proposed in 1933 by the National Instruction Ministry, as part of the official beginning of the Estado Novo, "The New State" or the "Second Republic, headed by António de Oliveira Salazar between 1932 and 1968.

The 1933 Constitution was considered to reflect a conservative-fascist, anti-communist, anti-socialist, anti-liberal and anti-colonial regime which avoided most of the totalitarian and pagan elements of Mussolini and Hitler.

\footnotetext{
'Medicine, Sackler Faculty of Medicine, Tel Aviv University, \& Reuth Medical Center, Tel Aviv, Israel

${ }^{2} \mathrm{PhD}$, Professor, University of Évora, Centre of Historical and Philosophical Studies, Portugal
}

\section{Corresponding author:}

Avi Ohry, 2 Sh. Hachail St, Tel Aviv 6904I, Israel.

Email: aohry@post.tau.ac.il 

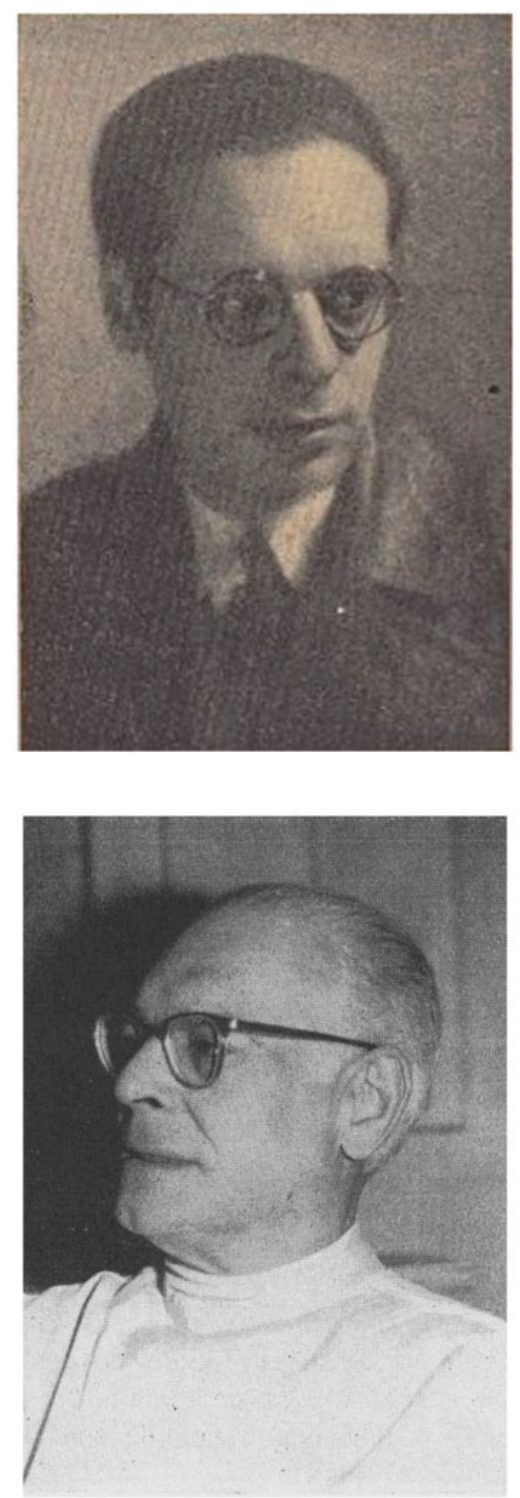

\section{Works}

d'Esaguy's writings appeared in newspaper editorials, in various exhibitions, and in books, and are outlined in his biography, written by the physician-professor of public health and historian of medicine Fernando Correia da Silva $(1893-1966){ }^{7}$ He contributed to the areas of culture, history of medicine and science, and the history of Jewish and non-Jewish Portuguese physicians. These included Isaac de Sequeira Samuda (1681-1729), ${ }^{8}$ physician, astrologer and poet, the first Jewish Fellow of the Royal Society, appointed a few years after escaping from the Portuguese Inquisition. Samuda became a bridge between the Portuguese and British scientific communities.
d'Esaguy showed that although he was a successful physician, Samuda's achievements were forgotten. However, his contemporary, Jacob de Castro Sarmento (1692-1762), ${ }^{9}$ became well appreciated. Sarmento, Samuda's friend and relative, was also elected to the Royal Society. d'Esaguy also wrote about Moisés Maimonides and Amatus Lusitanus, ${ }^{10}$ Balthazar (Isaac) Oróbio de Castro (1620-1689), a Jewish philosopher, physician and religious apologist, ${ }^{11}$ Ribeiro Sanches (1699-1783), ${ }^{12}$ Isaac Cardoso, ${ }^{13,14}$ and others.

d'Esaguy played an important scientific and cultural role in the pages of the Portuguese medical review Imprensa Médica (Medical Press) of the "Biblioteca da Faculdade de Medicina de Lisboa." He published articles on social diseases and tropical medicine, especially in Angola. He was also active in the general Portuguese public sphere: he contributed to the periodicals " $O$ Seculo," La Revue Juive de Gene've and to the "Emissora Nacional," the Portuguese national broadcasting review. "O Século" (The Century) was a Portuguese daily newspaper published in Lisbon, from 1881 to 1977 . The founder was the lawyer Sebastião de Magalhães Lima. It was a newspaper of record, and a great rival of the Diário de Notícias. O Século was owned by the Sociedade Nacional de Tipografia before the Carnation Revolution in 1974. Later on, D'Esaguy's colleague, Prof. Moisés Bensabat Amzalak (18921978) became the newspaper's owner. ${ }^{15} \mathrm{He}$ was a Portuguese scholar and economist who combined a successful business career with broad academic activity: president of the Academy of Sciences of Lisbon, deputy dean of the Technical University of Lisbon and dean from 1956 until his retirement in 1962.

In 1938, Augusto published an article on a 16th century Portuguese-Jewish physician in a local journal of the Jewish community in Geneva, Switzerland, ${ }^{16}$ adapted from a previous Portuguese work on the same subject. ${ }^{17}$ Garcia da Orta (1501/2?-1568) was a Portuguese Renaissance Sephardi Jewish physician, herbalist, and naturalist. He was a pioneer of tropical medicine, pharmacognosy and ethnobotany, who worked mainly in Goa, then a Portuguese overseas territory. There is a modern hospital which is named after him, Garcia Orta Hospital, Almada, Portugal, and a statue, made by Martins Correia, can be found at the Institute of Hygiene and Tropical Medicine in Lisbon. It is not clear whether, in this 1938 article, Augusto predicted that the fate of the Jews under Nazi rule would be similar to, or even worse than, their fate during centuries under the Catholic Inquisition, or whether he simply contributed an historical article to the journal. Reviewing the general topics of the journal 
(1932-1948), no similar historical medical article could be found. The scope of d'Esaguy's publications was broad. ${ }^{18-25}$

\section{Jewish-Portuguese Refugee Committee}

The young man who walked along the Quay d'Alcantara that Sunday morning in 1933 had other things to occupy his mind. Lecturer at the School of Medicine, doctor at the Dermatological Hospital, doctor of the police of Lisbon, and already twice secretary to the Minister of Foreign Affairs, d'Esaguy's life at 33 was fully taken up with his medical and literary activities. Once a week he lectured on medicine over the Portuguese wireless, twice weekly at the University of Coimbra. Already he had received the Ordem Militar de Sant'Iago da Espada, highest Portuguese decoration, and also the K.C. Ordem Nacional Merito Carlos Manuel de Cespedes from the Cuban Republic ... his life was changed when he met the three boats with German Jewish refugees. ${ }^{26}$

d'Esaguy was deeply involved with the JewishPortuguese Refugee Committee during the Second World War. His name appears in the list of the Jewish Rescuers of the Holocaust 1933-1945. ${ }^{27,28}$ The refugee committee called the Commisao Portuguesa de Assistencia aos Judeos Refugiados was headed by d'Esaguy. His Secretary was Samuel Sequerra. "In early June 1941, about 14,000 Jewish refugees required shelter and the Lisbon Jewish community had increased its expenditures for refugees from $\$ 400$ to $\$ 10,000$ in just four weeks." 29

The Portuguese historian and journalist, Jose Freire Antunes mentioned in his book "Jews in Portugal, Testimony of Fifty Men and Women" that d'Esaguy and Amsalak took care of the Jewish refugees who got visas from Aristides de Sousa Mendes do Amaral e Abranches (1885-1954), the Portuguese consul-general in the French city of Bordeaux who defied the orders of Salazar's regime by issuing visas and passports to an undetermined number of refugees fleeing Nazi Germany, including Jews. For this, Sousa Mendes was punished by the Salazar regime with one year's suspension on half-pay but afterwards he continued receiving his full consul salary until his death in 1954. Sousa Mendes was vindicated in 1988, more than a decade after the Carnation Revolution that toppled the Estado Novo. For his efforts to save Jewish refugees, Sousa Mendes was recognized by Israel as one of the Righteous Among the Nations, the first diplomat to be so honored, in $1966 .{ }^{30}$
d'Esaguy is mentioned in the correspondence between two eminent historians of medicine: Henry Sigerist and Owsei Temkin. ${ }^{31}$

\section{Acknowledgements}

The author thanks two distant relatives of Augusto d'Esaguy, Dr. João Carlos (Haim) Ezaguy Lopes Martins and Carlos Eddy Esaguy Nehab, who provided information.

\section{Declaration of conflicting interests}

The author(s) declared no potential conflicts of interest with respect to the research, authorship, and/or publication of this article.

\section{Funding}

The author(s) received no financial support for the research, authorship, and/or publication of this article.

\section{References and notes}

1. www.myheritage.co.il/names/augusto_esaguy (accessed 15 May 2018).

2. The Dermatological Hospital was Hospital do Desterro, old Desterro Monastery, or Antigo Claustro do Convento de Sao Bernardoand. It became a private urban building, www.publico.pt/2012/11/03/culturaipsilon/noticia/lx-factory-interessadano-hospital-do-desterro-1569884 (accessed 15 May 2018).

3. Figuras do Dia. Gazeta dos Caminhos de Ferro. 45 (1071). 1 de Agosto de 1932. p. 365. (accessed 15 May 2018).

4. Figuras do Dia . Gazeta dos Caminhos de Ferro. 45 (1069). 1 de Julho de 1932. p. 310. (accessed 15 May 2018).

5. Figuras do Dia . Gazeta dos Caminhos de Ferro. 46 (1101). 1 de Novembro de 1933. p. 580. (accessed 15 May 2018).

6. Koren N. Jewish physicians: a biographical index. Jerusalem. Israel University Press, 1973.

7. ciuhct.org/pt/correia-fernando-da-silva, 25.VII.1961, Medical Press (accessed 15 May 2018).

8. d'Esaguy A. Breve notícia sôbre o médico português Isaac de Sequeira Samuda. O Instituto 1934; 87: 262-269. (See also idem, A short note on Isaac de Sequeira Samuda. Bull Hist Med 1936; 4: 783-788).

9. d'Esaguy A. Uma carta inédita do Dr. Jacob de Castro Sarmento. Lisboa: Impr Médica, 1953.

10. d'Esaguy A. Oração e juramento médico de Moisés Maimonide e Amato Lusitano. Lisboa, 1955.

11. d'Esaguy A. The dramatic life of Oróbio de Castro. Bull Ins Hist Med 1937; 5: 822-826.

12. d'Esaguy A. A letter from Ribeiro Sanches addressed to the Marquis de Pombal. Scalpel (Brux) 1958; 111: 924-927.

13. d'Esaguy A. Isaac Cardoso, doctor, philosopher and poet. Bull Inst Hist Med 1938; 6: 163-170. 
14. d'Esaguy A. Histoire de la Médicine: Isaac Cardoso, médicin et Poète. Imprensa Médica 1951; 15: 171-174.

15. https://en.wikipedia.org/wiki/Mois\%C3\%A9s_Bensabat_ Amzalak (accessed 15 May 2018).

16. d'Esaguy A. Un me'decin juif portugais pendant l'Inquisition. La Revue Juive de Gene've 1937; 7: 319-320.

17. d'Esaguy A. Garcia D'Orta: físoco-mór del rei. Lisboa: Ática, 1934.

18. d'Esaguy A. La Bible et le Talmud. La Revue Juive de Gene've 1936; 38: 370-371.

19. d'Esaguy A. Letter of the Reverend Father Parrenin, dated at Peking, on the disease commonly caused by venereal disease. Scalpel (Brux) 1960; 113: 143-148.

20. d'Esaguy A. Apologia da agoa de Inglaterra da Real Fábrica (1812) (1931). (Sobrea Aİgua de Inglaterra). Imprensa Me'dica 1959; 23: 407-413.

21. d'Esaguy A. Grandezas e misérias de Israel. Paris: Presses Universitaires de France, 1939.

22. d'Esaguy A. A abertura da Escola Médica de São Paulo da Assunção de Luanda, 1791. Documentos. Lisboa, Editorial Imperio, 1951.

23. d'Esaguy A. Nótulas para a história da medicina de Angola. Documentos. Editorial Imperio, 1952.
24. d'Esaguy A. Fernando ou Isaac Cardoso: um erudito físico-mor. A Medicina Contemporânea 1931; 10: 85-86.

25. d'Esaguy A. Comentos à vida e obra de Elias Montalto. Imprensa Médica 1951; 1: 1-7.

26. Alsen ER. A letter from Portugal-fighting the cause of refugees. The American Jewish Outlook, 3 Dec 1940, p 2, http://digitalcollections.library.cmu.edu/awweb/awarchive type $=$ file \&item $=715112$. $($ accessed 6 June 2018).

27. www.jewishholocaustrescuers.com/Rescuers_D-G_.html (accessed 6 June 2018).

28. www.holocaustrescue.org/rescue-timelines/ (accessed 6 June 2018).

29. https://ipfs.io/ipfs/QmXoypizjW3WknFiJnKLwHCnL72 vedxjQkDDP1mXWo6uco/wiki/Mois\% $\% 3 \%$ A9s_ Bensabat_Amzalak.html.

30. https://en.wikipedia.org/wiki/Aristides_de_Sousa_Mendes.

31. Correspondence Henry E. Sigerist (1891-1957) - Owsei Temkin (1931-1956), Edited and annotated by Marcel H. Bickel, Bern, www.img.unibe.ch/unibe/portal/fak_medizin/ber_vkhum/inst_medhist/content/e40437/e40444/ e153944/section154575/files154582/Correspondence HenryE.Sigerist-OwseiTemkin_ger.pdf).

\section{Author biography}

Avi Ohry was born in Israel in 1948; Married +two daughters; Emeritus Professor of Rehabilitation Medicine, Sackler Faculty of Medicine, Tel Aviv University. Former Director of the Section of Rehabilitation Medicine, Reuth Medical Center, Tel Aviv. In 2005, selected to be featured in the Caring Physicians of the World publication, by the World Medical Association. Main topics of interest: neuro-rehabilitation, bio-ethics, history of medicine, Jewish-Polish medical infrastructure between the two World-Wars; long term effects of disability and captivity. He plays the (jazz) drums in two bands.

Maria de Fûtima Nunes is full Professor of History, at University of Évora and integrate researcher at the IHC Unit I\&D [Contemporary History Institute - http://ihc.fcsh.unl.pt/] Supervisor of the Research Group Science CEHFCi-UE. Domains of research and teaching: History of Culture and History of Scientific Culture - Modern and Contemporary times. She has the scientific coordination of the $\mathrm{PhD}$ on History and Philosophy of Science with Museology. She has different publications in these areas, having supervised several PhD theses with these research agendas, as comparative and international methodology. More details: http://www.uevora.pt/pessoas/ (id) $/ 4779$. 